\title{
“TWO MORE THROWS AGAINST OBLIVION": WALT WHITMAN AND THE NEW YORK HERALD IN 1888
}

\author{
ELIZABETH LORANG
}

In January 1888, Walt Whitman Began writing For the NEW York HERALD, one of the most important nineteenth-century American newspapers, in a relationship in part meant to save him from anonymity, a recurring concern for the aging poet. During this extremely productive period of Whitman's late life, thirty-one poems and two prose pieces appeared in the newspaper over a period of less than six months, and a total of thirty-six pieces were printed from December 1887 through August 1888. ${ }^{1}$ Yet despite Whitman's apparent hope that his relationship with the New York Herald would help rescue him from oblivion and despite the fact that far more of Whitman's poems appeared for the first time in the Herald than in any other periodical in which Whitman published, the newspaper has been largely ignored in Whitman criticism and the poems never studied in their original publication. This omission in Whitman scholarship is perhaps partly due to the overall imbalance in criticism on the poet's later life and works, the prevailing assumption being that Whitman in old age is neither as interesting nor as radical as the poet of the 1855 Leaves of Grass, nor as poignant as the poet of "When Lilacs Last in the Dooryard Bloom'd." If we accept, however, that periodicals were significant to Whitman's career, then the exclusion of the Herald in Whitman criticism is to the detriment of a more complete understanding of Whitman and his oeuvre in historical and literary contexts.

Examining this relationship, the most complex Whitman would ever have with a periodical, further develops our understanding of one of the very late years of Whitman's life. In addition, reading the Herald poems in their first instantiation requires that we see these late poems as a more significant body of work than previous critics have supposed, particularly in their generic function as newspaper poetry. Newspaper poetry of the nineteenth century, a once common feature of the daily papers, required certain formal qualities which Whitman would have understood well given the years he spent working for newspapers. In the Herald pieces, 
Whitman worked within this poetic tradition, crafting short poems that could be understood by a mass readership and that participated in the public discourse of the community in which they were published.

The story of Whitman following the publication of Leaves of Grass in 1855, his work in the Civil War, through to the centenary edition of Leaves of Grass in 1876 is well-documented in literary scholarship. These years, for many, comprise the most interesting decades of Whitman's life and mark a significant shift in his poetic form and ideology. With Leaves of Grass, Whitman moved beyond his frequently simplistic rendering of politics for more complicated representations, and he maintained this greater subtlety throughout the Civil War era, from the late antebellum period through Reconstruction. But many Whitman critics regularly see the poetry of the 1880 s and early 1890 s as simply "minor" and neither aesthetically nor thematically innovative, with a few exceptions for individual poems. M. Wynn Thomas admits that previous critics interested in securing a reputation for Whitman could not do so on the basis of his late or "geriatric" poetry "since it is obvious that Whitman's powers ... are not best recommended through a study of his poetry at what seems to be its weakest." 2 Thomas, however, hopes to contextualize, if not secure a place for, this late poetry within the corpus of Whitman's work, and reading the late poems of the New York Herald within their context in the paper does, in fact, increase and alter our understanding of them.

No doubt these poems will never rank among Whitman's highest achievements. And readers who come across the Herald poems only in the "Sands at Seventy" annex to Leaves of Grass likely will find them mere trifles, as these readers will almost certainly encounter them after having read "Song of Myself" and other powerful Whitman poems. We know, however, based on sales figures and popular response, that most readers of the New York Herald would not have read "Song of Myself" or much of Leaves of Grass, except those poems they might have found in other periodicals. For current readers and critics, then, the poems that come before the Herald poems in the final edition of Leaves-and those poems that are routinely singled out in the "greatest hits" approach adopted by some anthologies - can shadow our appreciation of the late pieces. Returning to the original print and cultural environments of the New York Herald poems allows us to see how the poems operated in the culture of the period and to read them within a more complete context.

Established by James Gordon Bennett in 1835, the New York Herald was one of the first successful penny papers-cheap newspapers that appealed to a mass readership - of the Jacksonian era. ${ }^{3}$ Though New York was already home to two successful such newspapers, the New York Sun and New York Transcript, Bennett hoped that a slightly modified 
formula, which mixed the sensational journalism and cheap price of the penny press with additional serious journalism written in a readable style, would cater to an unmet demand and appeal to an even larger audience than did these other papers. Realizing that a paper with many kinds of news would represent the interests of many types of readers who would buy an entire issue for a single column of interest to them, Bennett created in the Herald an eclectic mix of business, society, sporting, financial, and sensational news. As a result, by 1840, the Herald's circulation surpassed that of all other dailies in the United States. By 1857, the newspaper's circulation reached 70,000, and by the end of the Civil War circulation topped 131,000. ${ }^{4}$ In 1866, Bennett turned the editorship of the Herald over to his son, James Gordon Bennett, Jr. Under Bennett, Jr., the Herald's reputation for sensational stories and the broadest variety of news grew. Circulation also continued to grow in the 1870s, and the paper maintained its dominance throughout the decade. Bennett, Jr. sent Henry Morton Stanley to find David Livingstone and backed George Washington DeLong's ill-fated expedition to the North Pole, and he expended enormous sums of money in order to report breaking news. As a result of his management of the paper as well as his personal eccentricities, Bennett became both a celebrity and villain; indeed, critics who have attempted to offer an account of the Herald under the younger Bennett's reign tend to relate the life of the celebrity, playboy editor, rather than explore the paper itself. ${ }^{5}$ Challenged by Joseph Pulitzer's New York World, the Herald lost ground in the 1880 s. When Pulitzer purchased the World in 1883, his path to success nearly mirrored the efforts of Bennett fifty years earlier. Just as Bennett had drawn on the model of the Sun and Transcript, Pulitzer largely modeled the revamped World on the Herald. Also like Bennett, Pulitzer then built on the established formula to create a paper that would appeal to even more readers. In this way, Pulitzer quickly turned the World into the major New York newspaper, and by 1886 the Herald had lost its circulation lead to the World.$^{6}$ In 1888, however, Bennett continued to boast the Herald's previous circulation dominance by printing the circulation figure "190,500" under the heading "High Water Mark" as a standard daily feature of the paper.

Still printing both sensational news and marketing itself to a broad readership, the Herald followed an established format in 1888. The paper began with one or more pages of advertising for rooms, domestic situations, and goods; the first page also carried news of marriages and deaths. The remaining pages each comprised a specific section, identifiable by their stories: major, breaking news; sports; entertainment and errata; international news; financial and commercial news; miscellaneous news and additional advertising. In addition, local news 
was spread throughout the paper, as appropriate for the various sections. This format, however, contrasts starkly with the newer format of most popular newspapers of the 1870 s and 1880 s, where, among other changes, the front page carried breaking news and "fiction, poetry, religious material . . . drifted toward the back pages, along with local events, financial matters, crime, and all the other features of the everyday." 7 When challenged by the World, the Herald's conservative format perhaps further precipitated its loss of circulation. In 1888, the Herald ranged from twelve to twenty-eight or more pages and occasionally ran an octuple sheet (thirty-two pages) for its Sunday edition. Illustrations were not a regular feature of the Herald, but maps and figures appeared several times a month, most often accompanying transatlantic news, such as shipping routes. By this time, the paper had developed a less politically neutral stance in regularly attacking Republicans and supporting the Democrats' positions, though the paper remained independent of formal ties to political parties or organizations. But the Herald was an ardent and vocal supporter of President Grover Cleveland, both claiming responsibility for his 1884 victory and predicting a similar win in 1888 . The Herald took various opportunities to praise the President in its editorials and in letters from the public. On January 26, 1888, the Herald printed a letter from Walt Whitman about Cleveland in its "Personal Intelligence" column. Whitman's first contribution to the paper under an arrangement with Bennett, the letter was printed following the heading "Pleases Walt" and reads, in part, "Looking out from my 'loophole of retreat' I wish to heartily thank President Cleveland for his free trade message and for his jubilee gift to the Pope. Though voices and squads here and there (perhaps hundreds) will object thousands of America's quiet thinkers everywhere will be well satisfied" (6). ${ }^{8}$ In addition to such praise for the President, many short articles in the newspaper also regularly extolled Mrs. Cleveland, especially as a model wife.

Not surprisingly, sensational stories, particularly those dealing with strange deaths, could be found in essentially every issue of 1888 . Stories of murdering spouses, train collisions, shipwrecks, and lost ships were frequent. So too were details of nature run amok, including dramatic accounts of destructive tornadoes, crippling blizzards, earthquakes, and cyclones. Similarly, fire and its devastation proved an untiring theme, as it had from the emergence of the penny press in the 1830s. Many of these sensational stories were related to issues of industrialization, of which the Herald presented an often grim view. Explosions, such as that at the Dupont Powder Works, in which "[f] our men were blown into atoms," and gas leaks that silently killed individuals and families were regularly reported. Growing concomitantly with industrialization 
was immigration to the United States, and American hostility toward immigrants increased as well; both trends were apparent in the pages of the Herald, which probably helped to bolster nativism. The Herald linked Europeans with subversive politics, including socialism and anarchism. Articles early in the year warned of the arrival of more socialists in the United States and the growing problem in Europe, as well as mounting anarchist trouble on the European continent. Within the Herald, the United States was positioned as vulnerable to invasion from these revolutionary groups. Unlike many of the Herald's readers, Whitman defended an open immigration policy for the United States in 1888:

Restrict nothing - keep everything open: to Italy, to China, to anybody. I love America, I believe in America, because her belly can hold and digest all — anarchist, socialist, peacemakers, fighters, disturbers or degenerates of whatever sort-hold and digest all. If I felt that America could not do this I would be indifferent as between our institutions and any others. ${ }^{9}$

Despite the growing nativism in the United States, international news constituted a major part of the Herald, and the paper was genuinely interested in world affairs. Through June, the Herald published extensive news on the failing health and deaths of Emperor William of Germanyfor whom Whitman wrote "The Dead Emperor" for the paper-and his son William Frederick (Frederick III). The Herald's international news also focused on the mounting tensions between Russia and the Triple Alliance of Germany, Austria-Hungary, and Italy. As part of this unfolding tension, the Herald covered Russia's plans to build a Pacific railway and the subsequent response from England.

International conflict, however, was not without stateside company, and the Herald kept its readers updated on what it called the "HatfieldMcCoy Vendetta," or the "Kentucky and West Virginia War," as well as on continued racial conflict in the South. And in the year that Jack the Ripper struck in England, and the Herald sensationalized the murders, the newspaper also ran notice that all criminals in New York sentenced to death would be executed by means of electrocution, effective January 1,1889 . But the most pressing national topics covered in the Herald in 1888 were related to the rise of industrial capitalism. As robber barons and trusts came to dominate business, and invention, industrialization, and corruption seemed inherently intertwined, the Herald repeatedly featured Jay Gould as a subject of scorn. Multiple articles on trusts, monopolies, and labor strikes appeared in the newspaper daily. The Herald covered extensively the Reading Railroad and Shenandoah, Pennsylvania strikes as well as those by flint glass workers, miners, and cigar workers, among others. For some time, the Herald also predicted the revival of Molly Maguireism in the United States. Coinciding with 
this rampant labor unrest, the Herald daily reported the stock market as "dull" or "very dull," only infrequently offering a more promising forecast. Marked both by intermittent financial depression and the accrual of enormous wealth, American existence in the late 1880s seemed both grandiose and particularly tenuous. The looming century's end exacerbated this sense of fragility. Naturally, the pages of the 1888 Herald explored and exploited these anxieties with its readers. In addition, the Herald's extensive coverage of the deaths of nineteenth-century icons Matthew Arnold, Emperor William, William Frederick, and General Sheridan, among others, further signaled the end of an era. Walt Whitman's Herald poems appeared within this context, as part of this public discourse.

On New Year's Day 1888, the New York Herald ran a page of resolutions by famous individuals, communities, organizations, and Herald readers. Many of these resolutions, or "swearings off," were humorous, and more than a few were likely jokes drafted by Herald writers. Among the many resolutions purportedly telegraphed to the newspaper was one by Whitman. Carrying the dateline "Camden, Dec. 31, 1887-Walt Whitman," and the headline "The Naughty Gray Poet," the short piece read, "I'm not going to swear off. I'm going to be as ruggedly naughty as ever" (5). The piece, whether written by Whitman or not, is an appropriate one to mark the beginning of 1888 and the year's relationship between the poet and the paper. Near the end of January, Whitman and Bennett contracted an agreement for Whitman's poetry to appear regularly in the newspaper, and within a matter of months, the poems generated significant backlash in the press, though Whitman was probably better behaved than ever before. The relationship between Whitman and the Herald that emerged in the beginning of 1888 had been building over time, as his correspondence and other writings indicate. Familiar with the Herald from its founding, Whitman read the paper with some regularity, probably at first in a competitive effort as he began his own newspaper career. More than forty years before Whitman began appearing in its pages and about the time the Herald was becoming the nation-wide circulation leader in the 1840 s, Whitman wrote a scathing editorial for the New York Aurora in which he considered James Gordon Bennett, Sr. the real-life incarnation of the worst of Dickens's villains. On 2 April 1842, he wrote:

Why, almost within the reach of our voice, there is a palpable counterpart to the worst embodiment of evil that the brain of Dickens ever transcribed upon paper! . . A reptile marking his path with slime wherever he goes, and breathing mildew at every thing fresh and fragrant; a midnight ghoul, preying on rottenness and repulsive filth; . . . all this is James Gordon Bennett. . . . [This] loathsome agent of damnation claims the additional merit of having been spawned, not in an American gutter, but 
to have ornamented with the presence of his earlier age, some sty, pauper out house, or reeking bagnio, of his North Britain! ${ }^{10}$

Whether Whitman's sentiments about Bennett, Sr. ever changed is not known, but Whitman continued to read the newspaper. It was from the Herald, after all, that Whitman learned of George Washington Whitman's injury during the Civil War. And following the younger Bennett's rise to the editorship, Whitman solicited the paper as a venue for his work. In May 1876, as the Herald's circulation continued to climb, Whitman drafted a letter to the editor writing, "I merely write you a line to call attention ... to the poem I sent you some days since, Song of the Exposition ... proposed to be printed, if at all, in the paper for May 10, if acceptable at the price named." 11 The poem did not appear in the paper. Nearly five years later, in January 1881, Whitman wrote to his friend Jeanette Gilder - she had been the Herald's literary editor for a number of years and would later publish several of Whitman's late poems in her magazine the Critic - about the possibility of "exploiting" his piece "The Poetry of the Future" in the Herald (3:204-205). Though Whitman never would have submitted poems to the Herald during its first decades, from at least the late 1870 s, he became particularly interested, if not eager, in having some of his work appear in the Herald; the newspaper's circulation and broad reach almost certainly influenced Whitman's desire to appear in its pages. Then, on December 15, 1887, at the request of Herald literary editor Julius Chambers, Whitman contributed the poem "As the Greeks Signal Flame" [sic, hereafter regularized, "As the Greek's Signal Flame"] for the paper's celebration of John Greenleaf Whittier's eightieth birthday.

Following the appearance of "As the Greek's Signal Flame," Whitman again wrote to the Herald's editor, perhaps in an attempt to develop a stronger rapport with the paper: "Thanks for the handsome pay for the WHITTIER SONATA-Best regards to Mr. Bennett, Mr. Chambers \& all the boys" (Corr 4:136). Whether Whitman had been in direct correspondence with Bennett or simply working through his intermediaries prior to this time is not clear, but in late January 1888, he received a letter from the editor. In a message to Richard Maurice Bucke on January 24, Whitman summarized the correspondence: "I rec'd a letter this mn'g from N Y Herald, from J G B [ennett] himself asking me to write for the paper-" (Corr 4:143-144). According to the editor's note that accompanies this letter, Bennett asked Whitman for poems on any subject and told the poet, "The Herald would be very willing to pay a reasonable compensation for this work, and only as much as you desire need be signed. The stanzas need not contain more than 4 to 6 lines" (144). Horace Traubel gives a more complete account of the arrangement: Whitman's "contract with The Herald 
calls for ten pieces (no size stipulated) a month, for which he is paid one hundred dollars" ( $W W C$ 1:41-42). In a letter to Julius Chambers on March 7, however, Whitman wrote that he "would like to continue [the arrangement] for $\$ 40$ a month, \& will furnish [the Herald] with say ten pieces a month . . . this bargain to commence with the current month" (Corr 4:155). Though Whitman never quite met the arrangement of ten poems per month, thirty-one of his poems appeared in the Herald under this contract with the paper. ${ }^{12}$ A final poem, "[Over and through the burial chant]," later printed as "Interpolation Sounds" in Good-bye My Fancy, appeared in the paper on August 12, 1888, four days after Whitman's short prose tribute to General Sheridan, but not under the earlier contract. This poem on the death of Sheridan, written at Bennett's request, would be Whitman's last printed contribution to the paper. The previous month, on July 3, Whitman had sent a letter to Bennett and Julius Chambers to thank them for their recent payment (despite the fact that Whitman had not submitted any poems) and to let them know he would likely not be able to continue with their contract: "have not sent you a line for a month-\& probably will not any more-as I am ill from breaking out of old war-paralysis" (Corr $4: 181$ ). Whitman did submit at least one additional poem to the paper in 1889-"Bravo, Paris Exposition!"-but the poem was rejected by both daily circulation leaders, the Herald (which had also rejected his 1876 exposition poem) and Pulitzer's World, before being printed in Harper's Weekly on September 28, 1889 (WWC 5:280; 6:19).

Ultimately the relationship that developed between Whitman and the Herald was advantageous to both parties. The paper provided Whitman with a steady income and placed no demands on his poems. With its large circulation, the paper offered Whitman a readership unprecedented by any of the newspapers in which he had previously published and probably the greatest readership he had in his lifetime. The publication of Whitman's poems may also have been a move of desperation for the Herald, which was suffering by 1888 , given the major success of the World, now the circulation leader. For the Herald, then, Whitman in his old age and increasing fame provided the allure of celebrity. Yet even the two most recent biographies of Whitman, Jerome Loving's Walt Whitman: The Song of Himself and David Reynolds's Walt Whitman's America, say very little about either the Herald poems themselves or the newspaper. Loving writes only that November Boughs "contained the essays and poems published since Specimen Days, including poems written in an open contract for the New York Herald between January 27 and May 27, 1888." ${ }^{\prime 3}$ Reynolds also effectively dismisses the poems and the paper. Picking up on an editorial note from the Daybooks and Notebooks, Reynolds does call Whitman the "poet laureate of the nation's 
most popular newspaper" and sees Whitman's appearance in the paper as his "greatest publicity coup of the period" (565); but the Herald was no longer the most popular newspaper, and Reynolds underestimates the overall significance of this "coup," as well as the poetry itself. While the Herald provided the "famous sick old man" with "the opportunity to say something to America," he had "little new to say," and was "beyond even thinking about writing a sweeping, cohesive poem about America" (565). Such comments and dismissals suggest a much less complex relationship than actually existed between Whitman and the Herald as well as a somewhat simplified reading of the Herald poems and their function as newspaper poetry. On the contrary, details from both Whitman's correspondence and Traubel's accounts of Whitman's relationship with the Herald, as well as Whitman's works published in the paper, complicate our understanding of the arrangement and its importance.

As the letter above-in which the poet writes that he had received a letter from "J G B himself"-indicates, Whitman must have thought his new relationship with the Herald significant; the letter did not come from the literary or managing editor, but from "Bennett himself." Whitman wrote a similar letter to William Sloane Kennedy the same day, and from the end of January 1888 through May, Whitman continuously updated Bucke, Kennedy, William Douglas O'Connor, and others on the status of his publishing with the Herald. In instances like these, Whitman recognized the cultural significance of the paper and, relentless self-promoter that he was, the effects publishing in the Herald might have on his late career. At the same time, however, Whitman did not always submit his poems to the Herald first, on occasion offering the paper works that had been rejected elsewhere (WWC 1:37, 179-180; Corr 4:164). This practice shows that Whitman maintained an interest in placing his poems in several outlets and may raise some questions as to how highly he conceived of the Herald as a venue for his poetry. But financial motivations likely played some role in Whitman's desire to publish in multiple outlets: he could send any poem to the Herald and get paid, but if he also appeared in another newspaper or magazine, he could earn money on top of that from the Herald.

In other ways, too, Whitman appeared conflicted in his attitude toward the paper and bothered by the quality of his work. In one instance, he tells Traubel, "I have this afternoon mailed two pieces to the Herald - two more throws against oblivion" (WWC 1:77). Here, he suggests his appearances in the paper are an immediate means to remind the public of his still being alive and, more pointedly, a way to combat being forgotten. In considering his work for the Herald as a series of "throws against oblivion," Whitman's relationship with the 
paper is inextricably linked to anxieties about legacy, which permeated the poet's thoughts in 1888. Following Matthew Arnold's death on April 15,1888 - for many a harbinger of the end of an era-Whitman wrote a short piece for the Herald on Arnold's American legacy. According to Whitman's article, which appeared in the paper on April 18,

[A] character like Arnold's has a meaning and influence in literature, for we welcome all kinds, and indeed the glory of our age is that it would leave no voice, no claim unrecognized. But the fine gentleman, the purist, even the fine scholar, was probably never really less called for. Literature is already overweighed with them, and henceforth revolts from being a mere profession, a select class. I doubt whether America will miss Arnold at all. We miss Carlyle hugely, and the taking away of Tennyson would make a great void here in the emotions and aesthetic intellect of the United States. There are three or four great scientists to-day in the British islands any of whose deaths would cause chills here. But I don't think anything of the kind will happen in the present case. (8)

Though specifically about the death of Arnold as well as the impact of British authors (and scientists) on American culture in general, the paragraph also makes clear Whitman's own apprehension about passing into oblivion. He implicitly sets himself in opposition to Arnold, the purist, the fine scholar, and the literary professional, and suggests the reasons America will not long cherish Arnold are the same reasons America will feel a void at Whitman's passing. But surely there is some irony in the statement that "the glory of our age is that it would leave no voice . . unrecognized," since Whitman was, himself, still struggling for recognition in 1888. And it is in the irony, and between what Whitman writes about Arnold and what he implies about himself, as well as in Whitman's Herald poems, that we find his anxiety. As his comment to Traubel indicates, however, Whitman's continued presence in the Herald allowed him to maintain a public presence and an opportunity to combat nothingness.

At other moments, Whitman appears unconvinced of the efficacy of his Herald coup. Some time after the "two more throws against oblivion" remark and in a slightly different mood, he commented to Traubel on the Herald's publication of "A Carol Closing Sixty-Nine": "The list grows but what's the use of it?" (WWC 1:182). As these examples illustrate, Whitman developed an almost schizophrenic attitude about the Herald. On the one hand, publication in the paper seemed to offer Whitman longevity and the opportunity to postpone inevitable silence. On the other, he saw his work there as pointless or without meaning, for along with questioning the use of writing for the Herald, Whitman was also ambivalent about reading his poems in the paper. At least, this account of the ambivalent Whitman permeates the conversations with 
Traubel, in which we learn that Whitman's subscription to the Herald sometimes lapses, or the paper is no longer sent, or that Whitman has not himself read some of the poems, instead asking Traubel about their appearance in the paper. For all this ambivalence, though, Whitman surely counted on the Herald poems to serve as prepublication advertising for the forthcoming but incomplete November Boughs, and in letters to friends he inquired whether they had seen his latest "little bits."

Readers of the Herald certainly did see his poems. With the exception of "As the Greek's Signal Flame" and "[Over and through the burial chant],"which were included in larger stories on Whittier and Sheridan, Whitman's Herald poems appeared on the same page, in the same column, in every occurrence. The editorial and exchange page was located in the middle of the newspaper and was devoted to entertainment news, weather forecasts, various tidbits of light news, letters from readers, humorous clips from other papers, and endorsements of the Herald. Whitman's poems appeared in the "Personal Intelligence" column, which began with a detailed weather forecast and contained a variety of short anecdotes, letters, and poems, many of which were often clips from other newspapers. Given the nature of the page, Whitman's presence there may at first seem counterintuitive: the news on the page was slight, ephemeral, and watered-down. And while these adjectives may, in fact, be some of the more critical that come to mind, the page was probably one of the most popular in the newspaper because of the very kinds of information it offered, including sentence-long summaries of major international, national, and local news stories. Moreover, the page featured subscription and advertising information for all editions of the Herald, as well as the address of the paper and Bennett's name as proprietor. This page, more than any other, offered something for everyone: businessmen and individuals looking to advertise in the paper; readers seeking subscriptions; those with neither the time to read nor interest in the full-length news stories; everyone wanting to know the weather forecast (and who does not?); people looking for the day's entertainment; and those looking for a bit of humor, as the page invariably printed several short witticisms. The faithful reader could also regularly follow both serious and light-hearted discussions about a number of topics including politics, philanthropy, and, in the case of Whitman, poetry for several days or weeks at a time. In addition, the page sang the praises of the Herald and told readers why they should read the paper. First and foremost, the Herald was one of the most widely read newspapers in the United States (probably second only to Pulitzer's World until the arrival of William Randolph Hearst in New York in 1894) and had an unmatched international following. The page touted both of these achievements with the standard "High Water Mark" 
headline and 190,500 circulation figure, mentioned above, and notice that the paper received "cable messages for all parts of Europe" at its Broadway office. The page also frequently featured testimonials in the form of letters to the editor in which readers would write of their bad experiences with another paper - the World? - and their grateful return to the Herald. Thus, regardless of what other pages people skipped, they would stop over this one for any number of reasons. Whitman's presence on the page, which may have initially seemed idiosyncratic to today's reader, makes complete sense: the page, perhaps more than any other in the paper, promised the poet an audience and provided Bennett a place to parade a celebrity author. ${ }^{14}$

Though neither Whitman's correspondence nor Traubel records much about the public's reaction to Whitman's Herald poems, one of Whitman's letters does suggest the poems provoked conversation. In a note to Bucke on April 8, 1888, Whitman wrote, "- there seems to be some hitch in the Herald's publishing my little pieces-(I hear that they have been appealed to in print to stop publishing such stuff) -." (Corr 4:160). The publication record supports Whitman's suspicion, as nine of his poems appeared in both February and March, but only four were published in April, all within a two-week period. (On April 30, 1888, the paper also reprinted "The Bravest Soldiers," which had earlier appeared in the Herald, on March 18. $)^{15}$ Otherwise Whitman had a noticeably sparer presence in the paper than in the preceding months. No clear explanation exists as to why so few of Whitman's poems appeared in the Herald in April, and a number of factors, including Whitman's poor health, probably contributed to his absence from the paper. Another reason, however, as Whitman suggests to Bucke, may have been the response of readers to his poems.

Indeed, in March and April, Whitman and his poetry received a good deal of criticism in the "Personal Intelligence" column. The backlash largely stemmed from his seemingly innocent, and not at all naughty, poem "The First Dandelion," published in the paper on March 12,1888 . The poem, which followed up one of his February contributions to the paper, "Soon Shall the Winter's Foil Be Here," hearkened the coming of spring:

Simple and fresh and fair from winter's close emerging,

As if no artifice of fashion, business, politics, had ever been,

Forth from its sunny nook of shelter'd grass-innocent, golden, calm as the dawn,

The spring's first dandelion shows its trustful face.

At first glance, the poem hardly seems like one of Whitman's more controversial pieces, and critical work on Whitman's poetry has paid little attention to this apparently innocuous poem. When the poem 
appeared in the Herald the weather forecast printed on the same page predicted "partly cloudy to fair weather," with "slightly warmer, fair weather" for the next day. Juxtaposed with this forecast, the welcoming of spring in "The First Dandelion" certainly seems appropriate. But with rather poor timing for the publication of the poem, the crippling Great Blizzard of 1888 hit New York and the coast late on the evening of March 12, and continued throughout the $13^{\text {th }}$ and much of the $14^{\text {th }}$ in New York and other eastern cities. The Great Blizzard followed a similar storm two months earlier in the plains region of the United States, including the Dakota Territory. This earlier storm had caused the deaths of hundreds of people and had been reported extensively in the Herald. Therefore, though Whitman had not been alone in his welcoming of spring-like weather, he and his little poem emerged as an easy scapegoat when the Great Blizzard hit. Almost immediately the snow-bound took their ire out on Whitman in poems of their own. "The First Blizzard," signed "After Walt Whitman," appeared in the Herald on March 14, and a second poem, "Served Him Right," was printed in the column the next day:

The poet began an ode to spring-

"Hail, lusty March! Thy airs inspire

My muse of flowers and love to sing-"

And then the blizzard struck his lyre. (4)

A few days later, on March 18, Whitman remained the object of public scorn. This time, "Personal Intelligence" reprinted a clip from the Buffalo Express, which cheekily detailed how New Yorkers had passed their days during the blizzard and subsequent isolation: "by printing poems of Walt Whitman's on such seasonable themes as 'The First Dandelion.' We join Walt in admiration for dandelion salad" (14). Unfortunately, after returning to safer subject matter with "The Wallabout Martyrs" (March 16) and "The Bravest Soldiers" (March 18), Whitman followed with another poem that aggravated the snow-weary coast, "Orange Buds by Mail from Florida" (March 19). In a piece reprinted in the Herald on March 21 under the title "Work for Our Poet," the Hartford Times both criticized the larger premise of the poem and offered its own jab about the blizzard:

Walt Whitman writes a few lines to the New York Herald on a bunch of oranges from Florida, received by mail, and assumes it is a greater proof of civilization and progress than the ship of war and the grand opera which Voltaire claimed were evidence of France. Now, if Walt will poeticize a little on a lump of coal from Nova Scotia, and tell us of the civilization and progress that place a governmental tax upon it, we will gratefully welcome him to our homes and hearts in this day of blizzards. (6) 
Whitman had at least one defender, however. In a letter to the editor printed in the column on March 28, a Herald reader wrote, "The old gray poet deserves well of his country and his countrymen. He has always carried a very red blood in his veins; he has ventured much and suffered much for his race, and his views on early spring, or even upon 'the beautiful snow,' will always be fresh as a daisy ..." (6). Signed "Alexander Secundus," likely a pseudonym, the letter was perhaps written and planted by John Burroughs, Bucke, or, most probably, O'Connor. Despite this defense, Whitman's untimely poem remained in the public consciousness more than a month later. With spring now unquestionably imminent, the Herald proclaimed, "If this sunshine has courage, Mr. Whitman's beautiful fancy of the spring's first dandelion, coming with the truthful face ... will soon be realized" (16). While neither "The First Dandelion" nor "Orange Buds by Mail from Florida" may have prompted such a public response without the snowstorm, and the poems may have otherwise been received rather well or at least silently, the blizzard proved fortuitous for later literary critics and historians. Without the snowstorm, the public's response to "The First Dandelion," and the subsequent free-for-all on Whitman's Herald poems, we would be hard-pressed to know anything about how widespread the readership of these late poems really was. Reading "The First Dandelion" in its original publication and context shows clearly that people in New York and elsewhere were reading Whitman's Herald poems and were doing so in numbers unprecedented for his earlier work. The poems reached a huge audience and were the subject of considerable conversation.

Consequently, the Herald had little to gain by "some hitch" in printing Whitman's poems, such as the one the poet mentions in his letter to Bucke. In fact, given the strong-armed competition of the World, Bennett must have welcomed just the sort of discussion and controversy (mild as it was) that Whitman's poems were generating. Demands from the public to stop publishing Whitman's poetry would have further encouraged Bennett and Chambers in their efforts. While notes in the edited correspondence suggest an unresolved issue regarding Whitman's March bill was responsible for the lapse in publication, Whitman's records also show some confusion about his submissions to the newspaper, and the Herald may simply not have had poems to print. In one case, Whitman notes that he sent "Broadway" to the Herald on both March 3 and April 9, and the poem appeared on April 10. ${ }^{16}$ The Herald may have lost the first copy of the poem, but it is similarly possible that Whitman had not sent it in March after all. A second example helps corroborate the possibility of some confusion on Whitman's end about his submissions. According to his records, Whitman submitted "The Bravest Soldiers" to the Herald on March 2. The poem appeared 
in the paper on March 18. On April 28, however, Whitman's records show that he again submitted "The Bravest Soldiers" and note its printing on April 30 (DBN 453). Perhaps Whitman simply thought he had more poems waiting to be published at the Herald office, for he also records having sent "A Font of Type" to the Herald on two different occasions, though it did not appear in the paper. And perhaps Whitman chose not to send more poems to the paper for a period of time following the public reaction to "The First Dandelion" and "Orange Buds by Mail From Florida"; the criticism generated by the poems, for circumstances well beyond Whitman's control, must have provoked some feelings of frustration, but Traubel records no such information. Regardless of the reason behind the lapse, however, Whitman's lack of poems in the paper in April did not signal the poet's total absence from the "Personal Intelligence" column.

Possibly in an effort to supplement the lack of new poems in April and to continue to reap the rewards of the dandelion controversy, the Herald worked Whitman in to the column in other ways. Early in the month and prior to the resolution of the publishing hitch, the column featured two newspapers' responses to Whitman's poem "Continuities," the most recent of Whitman's pieces to appear in the paper, on March 20. These responses, in addition to maintaining Whitman's presence in the paper, also indicate the national readership Whitman's Herald poems received. On April 1, the New York Herald excerpted the Chicago Herald: "Nothing is ever really lost, or can be lost,' [the first line of "Continuities"] sings Walt Whitman. Walt appears to have never played poker" (14). Two days later, the Herald printed a companion clip from the Mobile Register. Following the tagline "A Natural Deduction" the piece reads, "'Nothing is ever really lost, or can be lost,' sings Walt Whitman. Mr. Whitman does not wear collar buttons" (6). As mentioned above, Whitman returned to the Herald on April 10 with "Broadway." On April 13, the paper printed an announcement of a Glasgow firm's plans to offer a book of Whitman's for publication by subscription, and on April 18 the piece by Whitman on the death of Matthew Arnold appeared. Two days later, the Herald reprinted an anecdote from the Chicago Tribune. The anecdote, with the title "Can't Rhyme for Shucks," recounts a conversation between a young man from St. Louis and a young woman from Boston. The young man asks Miss Howjames if she has seen any of the poems " "written by Walt Whitman for the New York Herald-?" to which she responds, "I am not in the habit of reading anything by the person you mention." "More interested in impressing Miss Howjames than standing up for Whitman, the young man concludes, after stammering, "II am not dead stuck on him myself. He can't rhyme for shucks. He makes anxiety rhyme with nitro-glycerin'” (6). 
In such instances, the Herald advertised both itself and Whitman. By citing clips from other papers that mention the Herald and the poet by name, the Herald commented on its extensive readership and cultural role; a reporter of news, the Herald also made the news across the nation. As Thomas Leonard points out, this practice of reprinting clips from other newspapers "allowed editors to show readers that the very publication they were holding had impact across the country. . . This was editing of the news to confer authority on the very paper that the reader was reading." ${ }^{\prime 17}$ Reprinted in the Herald, the excerpts advertised the Herald's connection to Whitman and encouraged more readers to buy the paper if for no other reason than to look for Whitman's seemingly easily-mocked poems. In addition, such pieces, along with the return of "Mr. Whitman's beautiful fancy of the spring's first dandelion" (April 22) and the reprinting of "The Bravest Soldiers" (April 30), allowed the Herald to maintain Whitman's presence in the column, even in the relative absence of his poetry. The paper had a significant interest in developing this more permanent role for Whitman, especially after the public response generated by his March poems.

Whitman returned to the Herald with seven poems in May, after publishing only four new pieces in April. In June, however, Whitman's health again grew worse, and he published no poems in the Herald. His May poems would, in fact, be his last contributions to the Herald, with the exception of "[Over and through the burial chant]" published in August. Throughout June, as in April, the Herald maintained Whitman's presence in the newspaper in other ways, primarily by carrying coverage of his birthday and declining health. On June 12, 1888, the Herald pronounced Whitman very near death, and on June 16 the paper reprinted a premature eulogy of sorts from the Chicago Herald, which with its peculiar shifting of tenses, suggests the poet had already died:

Walt Whitman is a poet who refused to be ground in the small mortar of human conventionality. Like Wagner in music, he thought he had a new idea, and resolutely, through a long life, impressed the individuality of that idea on the literature of the new world. It cannot be said that his poetry is good, but it may be maintained that he copied it nowhere. Whether he could write poetry or not, he deserved the thanks of all the Americans for dealing metrical form and ceremony the deadliest blow it has ever received. (6)

At the beginning of June, Julius Chambers and Bennett probably thought they were again holding a place for Whitman until new poems arrived and therefore wanted to keep his name and poetry fresh in readers' minds. By the middle of the month, however, as Whitman's health worsened, the editors quite possibly prepared for the poet's death as the most fitting, and profitable, conclusion to the previous five-month 
long conversation. Regardless, Bennett would have wanted to prolong Whitman's presence as long as possible, either for an eventual return or to lead up to his death and its subsequent coverage. The Herald could only benefit from the publicity, negative or otherwise. In the same way, for the duration of the contract, Whitman benefited from his connection to the paper and relied on the association of his name with the Herald to advertise his work. Certainly, then, neither Whitman nor the Herald considered their relationship simple or inconsequential.

Conflicted at times about both the quality and content of his later poems, including those that appeared in the Herald, and their relation to his larger body of work, Whitman ultimately decided in their favor, telling Traubel in June 1888:

I often ask myself, is the expression of the life of an old man consonant with the fresher, earlier, delvings, faiths, hopes, stated in the original Leaves? I have my doubts - minor doubts-but somehow I decide the case finally on my own side. It belongs to the scheme of the book ... Am I, as some think, losing grip?-taking in my horns? Nono-no: I am sure that could not be. I still wish to be, am, the radical of my stronger days - to be the same uncompromising oracle of democracy - to maintain undimmed the light of my deepest faith ... The Sands have to be taken as the utterances of an old man-a very old man. I desire that they may be interpreted as confirmations, not denials, of the work that has preceded . . I recognize, have always recognized, the importance of the lusty, strong-limbed, big-bodied American of the Leaves: I do not abate one atom of that belief now, today. But I hold to something more than that, too, and claim a full, not a partial judgment upon my work-I am not to be known as a piece of something but as a totality. (WWC 1:271-272)

Whitman thus cautions us not to excise these late poems from his corpus, but to read them as part of his canon. We are not bound to his injunction, of course. But we should keep it in mind when Reynolds and others see the Whitman of the Herald poems as largely incapable: incapable of writing a substantive poem about America and incapable of saying something new or significant. What such readings ignore is the degree to which the pieces widen the panorama of Whitman's democratic poetry to include those visions of old age not represented in his earlier works. They are not refutations of his earlier representations but complements and complications of them. The Herald poems participate in the discussions and engage in ideas central to Whitman's poetry since 1855, though the poems' interpretations of these ideas are understandably different. If, as Harold Aspiz claims, Whitman "realized from the outset of his poetic career that if his poetry were to reflect the essence and scope of our life experiences - and those of his own life-it must speak of death openly, imaginatively, and unswayed by clichés or established doctrines," $" 18$ then we should not be surprised, in 
the Herald poems, to come across a depiction of the "sick old man" or be necessarily inclined to read the sick old man as insignificant. Such a defense of the Herald poems, however, one based on pointing out the ways in which the pieces do, in fact, follow the philosophical trajectory of Whitman's work, is not the most useful nor the most compelling case for reappraising the Herald pieces. Instead, if we consider the formal and functional qualities of the pieces as newspaper poetry, we begin to get at a more thoughtful and nuanced reading of the Herald poems.

Unfortunately, newspaper poetry of the nineteenth century remains understudied, and there is virtually no scholarship on the topic, aside from short descriptions of the genre in newspaper studies as a whole. Monographs that do explore poems first published in newspapers, such as Paula Bernat Bennett's Poets in the Public Sphere, largely remove the poems from the newspaper context and ignore the generic qualities dictated by the form and function of the newspaper. Even a cursory reading of such poems across the century, however, makes clear certain properties of the form: newspaper poems relate current events, news, or cultural debate; their content is frequently local to the communities in which they are published; the poems are often quite short; and newspaper poems can be understood by a mass readership. As a whole, Whitman's poems first published in newspapers share these characteristics. With the exception of the poems Whitman published in the bohemian New-York Saturday Press, his newspaper poems were occasional poems (not to be confused with "incidental," in the pejorative sense) that related current events; participated in political debate (particularly those published before 1855); were often local in their content (such as the publication of the "The Mississippi at Midnight" in the New Orleans Daily Crescent); and were fairly short and easily understood. All of these qualities serve the function of the popular newspaper, including reporting, creating or forging a sense of community, and appealing to a mass audience. Since Whitman began his poetic career in newspapers, and had extensive experience in the newspaper business, he undoubtedly understood these formal and functional qualities of newspaper poetry.

That Whitman's Herald poems share the qualities of his earlier newspaper poetry does not then signal a regression from his innovative work of the 1850s-1870s; rather, the Herald poems show Whitman working effectively in a genre that he understood well. For example, the lyric quality of Whitman's Herald poems, from a formal point of view and out of the newspaper context in which they were published, marks them as conservative and outmoded. But the lyric was one of the major forms of newspaper poetry in the nineteenth century, and the poems therefore participate in a particular tradition related to the 
work of the poems and the newspaper. And while newspaper poetry could and often did encourage new ideas, its function of appealing to a mass readership and encouraging conversation required formal restraint. Because newspaper poetry of the nineteenth century served a different function than that found in literary magazines or books and because this function had implications for both aesthetics and content, to evaluate Whitman's Herald poems primarily by standards created for poems first published in other genres is an inadequate and flawed approach. As Barnhurst and Nerone theorize about newspapers more generally, "the form constrains meaning making. Once readers enter the newspaper, they continue to make choices, but the form imposes tacit rules that allow for certain reading practices and work against others" (7). We can extrapolate from Barnhurst and Nerone's position to include reading practices of newspaper poetry, as well as to theorize about the forms of writing and critical inquiry the newspaper requires and makes possible. That is, the publication of Whitman's Herald poems in the newspaper automatically creates for them a different standard of writing, as well as an alternate frame of reading, than those that have been imposed on the poems in the past. Further, newspaper poetry requires that we conceive of a new, or additional, critical approach by which to evaluate the poetry, rather than imposing standards for writing first published in other genres. ${ }^{19} \mathrm{~A}$ measure by which we might begin to evaluate newspaper poetry is the degree to which the poems serve the function of the newspaper as a publishing genre, particularly in terms of the newspaper's commitment to forging a sense of community and its participation in cultural conversation. ${ }^{20}$

Within the Herald poems, Whitman effectively acts as touchstone for the community and reporter. The poems established a sense of community for readers of the paper, even if that community often came together in their criticism of his poetry. Similarly, they participated in the discourse of cultural anxiety advanced throughout the pages of the Herald and in the culture-at-large. The earlier discussion of the "First Dandelion" controversy and ensuing response from the Herald's community of readers perhaps best illustrates the first of these functions. One may argue that the ongoing conversation surrounding Whitman's poems in the Herald emerged only because of their poor timing during the Great Blizzard. Such an argument, however, overlooks the fact that for such a response to be possible at all, a significant community of readers had to be already invested in reading Whitman's Herald poems. In addition, if Whitman's Herald poems had been esoteric or on themes not immediately relevant to the Herald's readers, even the Great Blizzard could not have prompted a response. But as newspaper poems, the Herald pieces were rooted in the moment and in dialogue with the 
paper's readers. As such, they were participatory in public culture and able to elicit response from the public. In this way, Whitman's Herald poems served the forum function of the newspaper exceptionally well, as the letter from "Alexander Secundus" helps make apparent. And as David Paul Nord explains, the ability of a newspaper to act as a public forum is crucial to building a community of readers, a central function of the newspaper. ${ }^{21}$

In addition, and in relation, to their role in forging a sense of community, Whitman's poems participate in an ongoing, intertextual discourse on life and death developed throughout the pages of the Herald. As the century approached its twilight years, Whitman faced death and was well positioned to write about the United States' own uncertain future. According to Betsy Erkkila, Whitman's "crippled and disease-ridden body, old before its time, seemed once again an image of America itself at the close of the century. . . . Whitman's last poems are end-of-the-century poems ..." ${ }^{22}$ As end-of-the-century poems, the Herald pieces are complex in their engagement of the fin de siecle themes relevant to the aging Whitman as well as to the United States and the Herald's readers. Whitman gives poetic voice to the uncertain future on display throughout the Herald in 1888, and he variously speaks as comforter, commemorator, and suffering eye-witness. More than being simple "incidental" poems, pieces like "The First Dandelion," "Soon Shall Winter's Foil Be Here," "After the Dazzle of Day," and "A Prairie Sunset" record events of day-to-day life, but they also function as explorations of human and cultural mortality. Appropriately, Whitman summarizes this thematic unity across the works in "Continuities":

The body, sluggish, aged, cold - the embers left from earlier fires,

The light in the eye grown dim shall duly flame again;

The sun now low in the west rises for mornings and for noons continual;

To frozen clods ever the spring's invisible land returns,

With grass and flowers and summer fruits and corn.

For Whitman, such an understanding of the continuous nature of life, and death as part of life, is comforting in this instance. That Whitman felt inclined to do so much comforting, however, points to the pressing need for reassurance against a number of factors: for Whitman, seemingly imminent death and a questionable legacy; for the Herald, a similarly uncertain future; for the United States, tremendous uncertainty of its own. The anecdote about Mrs. Howjames, described above, further supports such a reading. Whitman had used neither "anxiety" nor "nitro-glycerin" in any of his Herald poems. The young man's choosing these words is therefore partly what makes the anecdote funny. But the choice of these words also suggests how the public 
interpreted Whitman's poems and further gives a sense of the anxiety and destruction in the culture-at-large. Ultimately, the characteristics that pervade Whitman's Herald poems - a sense of curiosity, checked by dread, shaded by optimism, and consumed by thoughts of growth and decay - are those that permeated his last years and the final decade of the nineteenth century. Given its own faltering existence, and the fin de siècle urban malaise depicted elsewhere in its pages, the New York Herald was perhaps the most suitable outlet for these expressions, and together the Herald and Whitman's poems offer a considerable intertextual record of the United States near the end of the century. The prevailing critical assessment of Whitman's Herald poems, which sees the poems as "health bulletins" having "little new to say," ignores the formal and functional characteristics of newspaper poetry and reads the poems outside of the contexts - textual and cultural-in which they were first published and read. By the very dictates of the newspaper poetry form, Whitman's Herald poems could not "provide a sweeping, cohesive poem about America." If we evaluate the Herald poems as newspaper poetry, however, we must begin to acknowledge their achievements in this genre.

Whitman hoped his Herald poems would help rescue him from oblivion and help secure his name in the late 1880s. But his Herald poems have remained one of the least studied parts of his career, despite their widespread notoriety in 1888 , their participation in larger cultural conversations of the period, and the hopes of both Whitman and the Herald that the pieces would save each from an uncertain future. This lack of contemporary criticism, however, is not surprising-and not because the poems lack, comparatively, the merits of Whitman's greatest works. Rather, though newspapers provided an unmatched audience, their very timeliness worked against longevity. Slason Thompson, in his collection of newspaper poetry from 1870-1885, already realized this problem of longevity. In fact, in determining what newspaper poems to include in his collection, Thompson began his consideration of every piece with a single question: "Does this poem . . . contain anything worth rescuing from oblivion?"23

University of Nebraska-Lincoln 


\section{NOTES}

I would like to thank Susan Belasco and Kenneth M. Price for their guidance, and I am indebted to them for their careful multiple readings, thoughtful comments, and provocative questions. Charles Johanningsmeier also provided helpful assistance, and I thank him as well.

1 Pieces printed from January 26, 1888, through May 27, 1888, constitute those contributed as part of Whitman's official contract with the Herald. Despite the fact that the contract called for poems, Whitman's first contribution after the agreement was a short prose piece on January 26, not the poem "To Those Who've Failed," which appeared on January 27.

2 M. Wynn Thomas, "A Study of Whitman's Late Poetry," Walt Whitman Review 27 (March 1981), 3-14. For more on Whitman's old-age poetry, see Donald Barlow Stauffer, "Walt Whitman in Old Age," Walt Whitman Review 24 (1978), 142-148.

3 Existing scholarship on the Herald privileges particular moments in the newspaper's history. This includes a much heavier interest in the newspaper from its founding in 1835 through the Civil War, and scholars are prone to retelling memorable anecdotes from this thirty-year period. Because a number of sources examine the founding and development of the Herald, and because this essay is primarily interested in the Herald in 1888, I have provided only those details relevant to a basic understanding of the newspaper and its importance in the nineteenth century.

For more detailed and specialized accounts of the New York Herald, see James L. Crouthamel, Bennett's New York Herald and the Rise of the Popular Press (Syracuse: Syracuse University Press, 1989); George H. Douglas, The Golden Age of The Newspaper (Westport, CT: Greenwood Press, 1999); Douglas Fermer, Fames Gordon Bennett and the New York Herald: A Study of Editorial Opinion in the Civil War Era, 1854-1867 (New York: St. Martin's, 1986); and Frank Luther Mott, History of American fournalism, Revised Edition (New York: The Macmillan Company, 1950).

Herald critics should keep in mind that the newspaper is a more complex one than it may initially seem. Two temptations arise when reading and studying the Herald: first, to overlook Bennett's more problematic moral positions, such as his early support for the Civil War and strident nativism, in favor of celebrating the significant advances Bennett helped pioneer in the emerging popular press; second, to overstate Bennett's personal, deplorable positions at the expense of overshadowing the many merits of the newspaper. The above studies point out a number of the newspaper's idiosyncrasies and seeming contradictions, but none deals with the full political and cultural complexities of the newspaper-certainly an enormous project. More than other authors, Crouthamel offers such a balanced view, but his work is limited to a study of the Herald under its founder, and no subsequent study has attempted a similar exploration of the Herald under James Gordon Bennett, Jr. The lack of scholarship on the Herald during the last three decades of the nineteenth century is a glaring omission in the existing criticism on the newspaper.

4 Crouthamel, 54, 151.

5 This trend to talk about the life of the younger Bennett in place of a focus on the Herald is even less useful when we consider the work of Kevin G. Barnhurst and John Nerone in The Form of Nerws: A History (New York: The Guilford Press, 2001). Barnhurst and Nerone have charted a shift in the newspaper form from the editor's newspaper to the publisher's newspaper in the $1870 \mathrm{~s}$. According to them, "although the editor retained a guiding hand in selecting news matter and still functioned as 
the chief voice of the newspaper, paramount control had passed into the hands of a proprietor who often played no editorial role" (73). Further, "The publisher's newspaper ... consisted internally of a proprietor controlling three different departments: editorial, production, and business. The divisions were still permeable, of course, and often the publisher also held the title of editor in chief. ... The publisher's newspaper, however, consisted of a more diverse network of relationships that often resulted in multivocal content" (75). In the case of the Herald, Bennett remained both editor and publisher, but since he spent the majority of his time in Europe, he had a network of people like Julius Chambers in New York making many day-to-day decisions on the newspaper's content. The overall direction of the paper remained up to Bennett, but his impact on its daily content-what made the Herald a newspaper-was considerably less than had been his father's.

To begin a discussion of the Herald under Bennett, Jr.- one which is interested in the newspaper more than the editor - this essay, along with examining Whitman in the Herald, explores in some detail the Herald during 1888 and places the 1888 Herald within cultural and historical contexts.

6 I have not been able to locate circulation figures for the World in 1888, but its circulation reached 250,000 by late 1886 or early 1887 , and the combined circulations of the morning and evening editions reached 375,000 in 1892 . Between 1870 and 1890, national newspaper circulation increased by more than 200 percent. See Douglas, 83-84, and Mott, 435.

7 Barnhurst and Nerone, 105. The authors continue, "Advertising filled in the cracks, sometimes up front, sometimes in back, but always clearly demarcated from news matter, and always now divided between mass retail and classifieds."

8 It is unclear where Whitman picked up the phrase "loophole of retreat." Although he possibly echoes Harriet Jacobs's Incidents in the Life of a Slave Girl, he is more likely quoting William Cowper's The Task (1785), a poem that was extremely popular in the nineteenth century. Whitman's private jottings indicate that he had some interest in Cowper's work but there is no corresponding evidence regarding Jacobs. See Notebooks and Unpublished Prose Manuscripts, ed. Edward Grier (New York: New York University Press, 1984), 5:1775, 1777.

9 Whitman quoted in Horace Traubel, With Walt Whitman in Camden: March 28-fuly 14, 1888, Vol. 1 (New York: Rowman and Littlefield, Inc., 1961), 113. See also Traubel's record of an anarchist's visit to Whitman in late April 1888 on page 65.

10 Walt Whitman, The fournalism, ed. Herbert Bergman, Vol. 1 (New York: Peter Lang Publishing, 1998), 93. For additional details contextualizing Whitman's characterization of Bennett, see David Reynolds, Walt Whitman's America: A Cultural Biography (New York: Knopf, 1995), 101, and Crouthamel, 32-36.

11 Walt Whitman, The Correspondence, ed. Edwin Haviland Miller, Vol. 4 (New York: New York University Press, 1961), 136. Hereafter Corr.

12 See "Walt Whitman's Poetry in Periodicals," part of the Walt Whitman Archiveavailable at whitmanarchive.org/published/periodical/index.html—for page images and complete transcriptions of the Herald poems. The poems published in the New York Herald between January 27 and May 27, 1888, are, in order of appearance, "To Those Who've Fail'd” (January 27, p. 6); "Halcyon Days” (January 29, p. 12); “After the Dazzle of Day" (February 3, p. 4); "America" (February 11, p. 4); "Abraham Lincoln (Born Feb. 12, 1809)" (February 12, p. 12); "True Conquerors" (February 15, p. 6); "Soon Shall Winter's Foil Be Here" (February 21, p. 6); "The Dismantled 
Ship" (February 23, p. 4); "Old Salt Kossabone" (February 25, p. 6); "Mannahatta" (February 27, p. 4); "Paumanok" (February 29, p. 6); "From Montauk Point" (March 1, p. 6); "My Canary Bird" (March 2, p. 6); "A Prairie Sunset" (March 9, p. 6); "The Dead Emperor" (March 10, p. 6); "The First Dandelion" (March 12, p. 4); "The Wallabout Martyrs" (March 16, p. 4); "The Bravest Soldiers" (March 18, p. 14); "Orange Buds by Mail from Florida" (March 19, p. 4); "Continuities" (March 20, p. 6); "Broadway" (April 10, p. 6); "Life" (April 15, p. 16); "The Final Lilt of Songs" (April 16, p. 4); "To-day and Thee"(April 23, p. 6); "Queries to My Seventieth Year" (May 2, p. 6); “The United States to Old World Critics" (May 8, p. 6); "Out of May's Shows Selected" (May 10, p. 6); "As I Sit Writing Here" (May 14, p. 4); "A Carol Closing Sixty-Nine" (May 21, p. 4); "Life and Death" (May 23, p. 6); and "The Calming Thought of All" (May 27, p. 12). All citations of these poems throughout this essay refer to their first printing in the New York Herald.

13 Jerome Loving, Walt Whitman: The Song of Himself (Berkeley, California: University of California Press, 1999), 460.

14 In the issues of the Herald examined for this essay, Whitman is the only author to receive such celebrity treatment from/in the newspaper. In addition, there is no evidence in existing Herald scholarship that suggests a similar, purposeful partnership between the Herald and other major American authors. A comparative analysis of the Herald's treatment of Whitman and its handling of other American authors, and the degree to which the newspaper cultivated literary celebrity, is a worthwhile point of investigation but is outside the scope of this essay. The most immediately available comparison to Whitman's presence in the Herald may be that of Mark Twain, who published a number of items in the Herald from the 1860s through the turn of the century. Twain's pieces, however, were not always signed, perhaps suggesting neither he nor the Herald considered their relationship in the same way as did Whitman and the Herald in 1888. Regardless, an exploration of Twain's works in the Herald and his relationship with the newspaper is an ideal place to start a comparative analysis.

15 "The Bravest Soldiers" appeared in the Herald on both March 18 and April 30 and was the only of Whitman's Herald poems to be reprinted in the paper during the course of the contract. There is no evidence to indicate that the Herald considered the poem particularly significant. Similarly, no news stories in the paper from around April 30 suggest a reason for the Herald's reprinting of the poem, but its reappearance at the end of April came during a temporary lull in Whitman's contributions to the paper.

16 Walt Whitman, Daybooks and Notebooks, ed. William White (New York: New York University Press, 1978), 2:452.

17 Thomas C. Leonard, News for All: America's Coming-of-Age with the Press (New York: Oxford University Press, 1995), 128.

18 Harold Aspiz, So Long!: Walt Whitman's Poetry of Death (Tuscaloosa: University of Alabama Press, 2004), 1.

19 While approaches to reading Whitman's newspaper poetry and other of his poems first published in magazines and journals may be similar, the forms are different enough in important ways to require that we not impose readings of one form onto another.

20 As more scholars study newspaper poetry as a form, additional criteria for discussing newspaper poems, as well as the ways in which newspaper poems were/are read, will emerge. In choosing to look at the ways in which Whitman's Herald poems participate in the larger discourse of the paper, as well as that of the community in which he was 
writing, and to look at the way in which Whitman's poems helped develop a sense of a community of readers, I am hoping to begin such conversations. I do not intend readers to consider my analysis here exhaustive, but rather introductory.

21 David Paul Nord, Communities of Fournalism: A History of American Newspapers and Their Readers (Urbana: University of Illinois Press, 2001).

22 Betsy Erkkila, Whitman the Political Poet (New York: Oxford University Press, 1989), 317.

23 Slason Thompson, The Humbler Poets: A Collection of Newspaper and Periodical Verse, 1870 to 1885, twelfth edition (Chicago: A. C. McClurg \& Co., 1908), 6. First published in 1885 . 